\title{
Self-action of a Gaussian beam in a nematic liquid crystal cell
}

\author{
V.Reshetnyak, S.Subota \\ Physics Faculty, Kyiv Taras Shevchenko University, \\ 6 Glushkova Ave., 03680 Kyiv, Ukraine
}

Received August 14, 2000

\begin{abstract}
We present a theoretical study of the possibility of optical singularity birth in a wave front of a laser beam passing through a homeotropically aligned nematic liquid crystal (LC) cell. At intensities below some threshold value there is no any distortion in the initial homogeneous homeotropic LC alignment. When light intensity becomes higher than this threshold value, LC director deviates from its initial orientation. Strong director anchoring at the cell walls is assumed. Inhomogeneous director profile leads to the modulation of refractive index which in its turn may be considered as a Gaussian lens formed in the LC cell. This lens gives birth to the phase singularities in coherent beam with initially smooth wave front. At small values of director deviation in geometrical optics approximation one can find the light field just after the LC cell, and utilizing the Huygens-Fresnel principle calculate spatial position of the phase singularity at near field as a function of intensity of the input beam.
\end{abstract}

Key words: liquid crystal, phase dislocations, phase singularities, light induced Frederiks transition

PACS: $61.30 . G d, 42.65 .-k, 42.70 . D f$

\section{Introduction}

In early 70's, the structure of wavefronts in monochromatic wave was analysed in detail by Nye and Berry [1] and by Wright [2]. It was shown that imperfections of regularity in optical wavefront can occur even in a pure monochromatic wave, namely screw and edge dislocations. Optical singularities are intriguing topological structures in modern optics. In [3] it was reported that the experimental study of the nucleation of wave front phase dislocations in a Gaussian beam experienced the self-action in a nematic liquid crystal. They investigated cases of normal and oblique incidence of the input beam. In the first case the appearance of circular edge dislocation was observed. In the case of oblique incidence, the situation resembles

*E-mail: reshet@marion.iop.kiev.ua 
the Gaussian beam passing the astigmatic lens. To describe this process theoretically it is necessary to solve the Maxwell's equations for light propagation simultaneously with equations for LC reorientation. We study this problem approximately. First we find the liquid crystal director profile in a nematic cell illuminated with Gaussian light beam, neglecting the feedback. After that the light diffraction caused by the director inhomogeneity is considered.

\section{Director profile}

In this paper we consider a homeotropically aligned nematic liquid crystal cell. Linearly polarised light with intensity $I=I_{0} \mathrm{e}^{-\rho^{2} / R^{2}}$ illuminates the cell. $O z$ axis of the Cartesian frame is along a non-perturbed direction of the director, and $O x$ axis is along the polarization of light. Strong director anchoring at the cell walls is assumed.

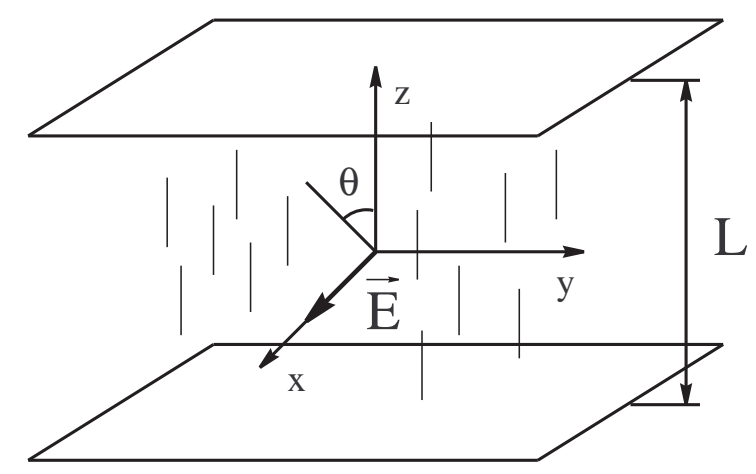

Figure 1. LC cell geometry, electrical field $\vec{E}$ and director orientation.

The total free energy to be minimized consists of two parts: elastic energy associated with the director deformation in the cell volume and interaction between liquid crystal and light beam. For simplicity we employ one elastic constant approximation, and in that case obviously director reorientation occurs in $X O Z$ plane. It is convenient to describe the director field by the angle $\theta$ between director and $O z$ axis:

$$
n=(\sin \theta, 0, \cos \theta) .
$$

The total free energy in a polar coordinate system now has the form:

$$
F=\frac{K}{2} \int_{V}\left(\left(\theta_{x}^{\prime}\right)^{2}+\left(\theta_{y}^{\prime}\right)^{2}+\left(\theta_{z}^{\prime}\right)^{2}\right) \mathrm{d} V-\frac{\epsilon_{a}}{16 \pi} \int_{V} \sin ^{2} \theta|E|^{2} \mathrm{~d} V
$$

where $K$ is elastic constant, $\epsilon_{a}$ is the anisotropy of the LC dielectric tensor, $V$ volume of the cell. To find the director profile under the action of Gaussian light beam we use the Ritz's variational method, namely we seek solution in the form:

$$
\theta=\theta_{0} \exp \left(-\frac{x^{2}+y^{2}}{a^{2}}\right) \sin \left(\frac{\pi z}{L}\right),
$$




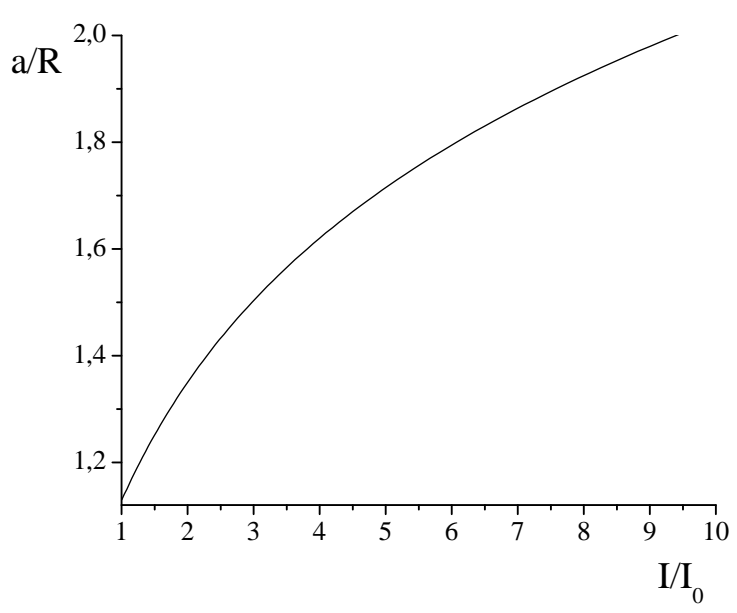

Figure 2. $a$ dependency on the intensity of light beam.

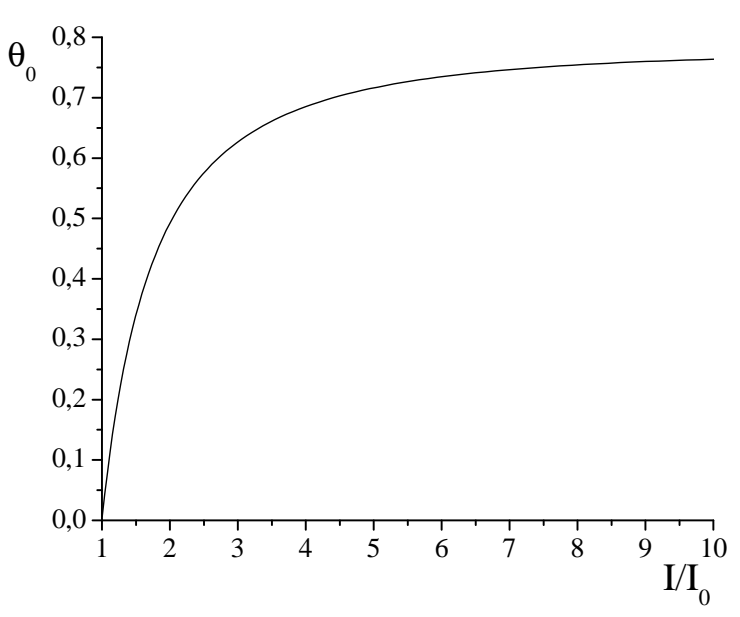

Figure 3. $\theta_{0}$ dependency on the intensity of light beam.

here $\mathrm{L}$ is the cell thickness. Substituting this expression into the free energy functional and integrating over $x, y, z$ we get free energy in a simpler functional form. Now free energy function depends on variables $a, \theta_{0}$ and intensity $I_{0}$ appears in it as the parameter. The necessary condition for minimum of the free energy function is that partial derivatives of $F$ with respect to $a, \theta_{0}$ are equal to zero simultaneously. This condition gives us a system of non-linear equations. Solving this system, we found that the director reorientation has a threshold behaviour. At intensities below some threshold value there is no distortion in the initial homogeneous homeotropic LC alignment. The director deviates from its initial direction at intensities higher than some threshold value. This threshold value of intensity is given by:

$$
I_{\mathrm{th}}=\frac{8 \pi K}{\epsilon_{a}}\left(\frac{\pi}{L}\right)^{2}\left(1+\frac{L}{\pi R}\right)^{2} .
$$

It is seen that at $L / R \ll 1$ the threshold intensity tends to a constant value, which coincides with a threshold of reorientation of the director in a field of a plane wave [4] and at $L / R \gg 1$ it increases very sharply. Similar behaviour of the threshold value of intensity upon ratio $L / R$ results was also obtained by Khoo et al. [5]. In figures 2,3 we plot the numerically found $a, \theta_{0}$ dependencies on the intensity of light beam.

Figure 4 presents the free energy for different values of intensity. It is seen that for values of intensity below threshold the free energy has minimal value only at $a$ and $\theta_{0}$ both equal to zero. For values of intensity higher than threshold, nontrivial minimum appears.

\section{Phase singularity birth}

Now we shall investigate Gaussian light beam diffraction caused by the inhomogeneous director profile, the last being found in the previous section. The appearance 


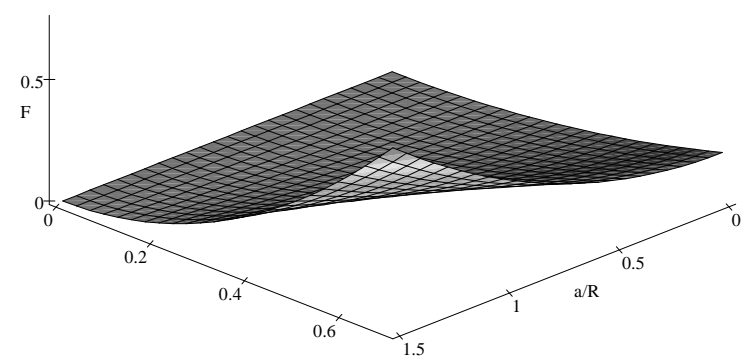

(a)

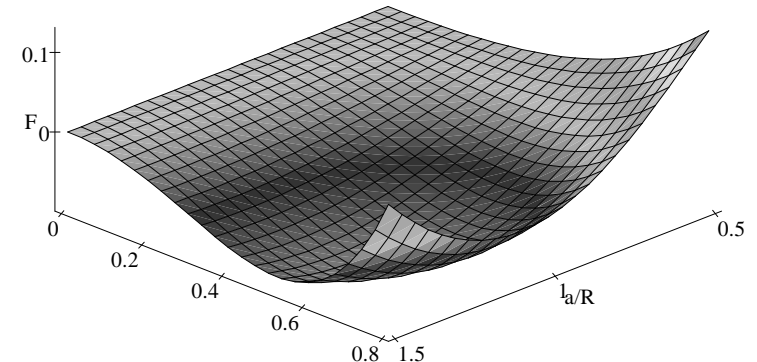

(b)

Figure 4. Free energy function $F\left(\theta_{0}, a\right)$ at the intensity (a) below threshold value, $I<I_{\text {th }}$ and (b) above threshold value, $I>I_{\text {th }}$.

of wavefront singularities, called optical vortices (OV), was observed experimentally in LC by Pishnyak et. al. [3]. A necessary condition of their existence is equality to zero of wave amplitude on some line being axis of vortex [6]. As a result in a light wave there appears a dark spot and the phase becomes undetermined. The line of zero amplitude can coincide with an axis of a light bundle, or to have a more composite behaviour. A special interest presents a case, at which the axis $\mathrm{V}$ is perpendicular to a direction of distribution of a bundle. Thus the edge dislocation of a wavefront is born. To find a light field behind LC cell we used the Huygens-Fresnel principle. Each point of a wavefront can be considered as a source of secondary spherical wave and these waves interfere. Mathematically, in Fresnel's approximation, which is correct in a short-range zone, the principle looks like [7]:

$$
U\left(x_{1}, y_{1}, z_{1}\right)=\frac{\mathrm{e}^{\mathrm{i} k z}}{\mathrm{i} \lambda z} \iint_{\Sigma} U(x, y) \exp \left\{\mathrm{i} \frac{k}{2 z}\left[\left(x_{1}-x\right)^{2}+\left(y_{1}-y\right)^{2}\right]\right\} \mathrm{d} x \mathrm{~d} y,
$$

where $U\left(x_{1}, y_{1}, z_{1}\right)$ is complex wave amplitude in a plane, which is at distance $z$ apart from the initial plane, $U(x, y)$ is the beam complex amplitude in the initial plane $z=z_{0}, k$ wave vector, $\lambda$-wavelength. To calculate the behaviour of the light field in our case it is necessary to know the light field at the exit of the cell. In a ray (geometrical optics) approximation this field has the form [8]:

$$
U(x, y) \sim|E|^{2} \exp \left(\mathrm{i} \frac{\omega}{c} \psi_{1}(L)\right)
$$

where

$$
\psi_{1}(L)=\int_{0}^{L} \frac{n_{o} n_{e}}{\left(n_{o}^{2} \sin ^{2} \theta+n_{e}^{2} \cos ^{2} \theta\right)^{1 / 2}} \mathrm{~d} z^{\prime}
$$

is the light phase retardation after passing through the cell, $\theta$ is the director deviation angle, which we have found in the previous section. We calculated numerically the changes of amplitude and phase of the light wave with distance from the cell for particular value of intensity, $I=1.045 I_{\text {th }}$. Figures 5,6 present light wave amplitude and phase as the function of radius for a different value of the distance $z$ from LC cell. When the distance $z$ increases, a local minimum appears in amplitude, while, at 


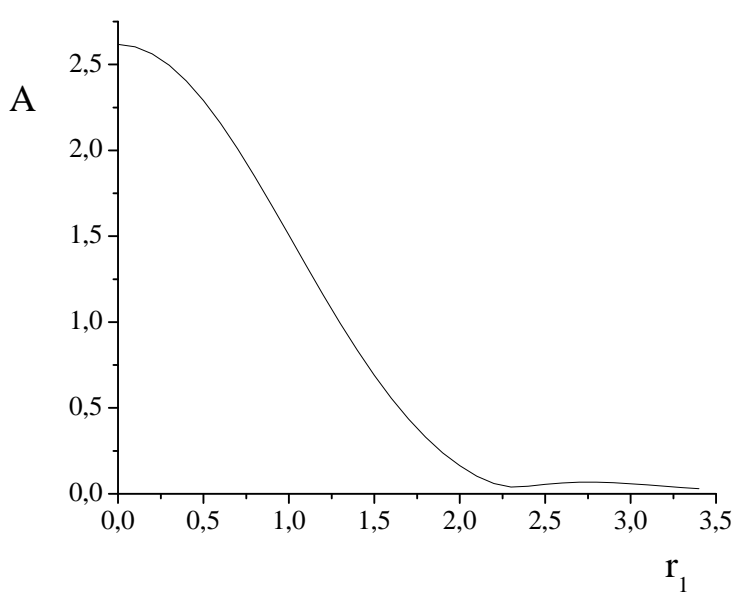

(a)

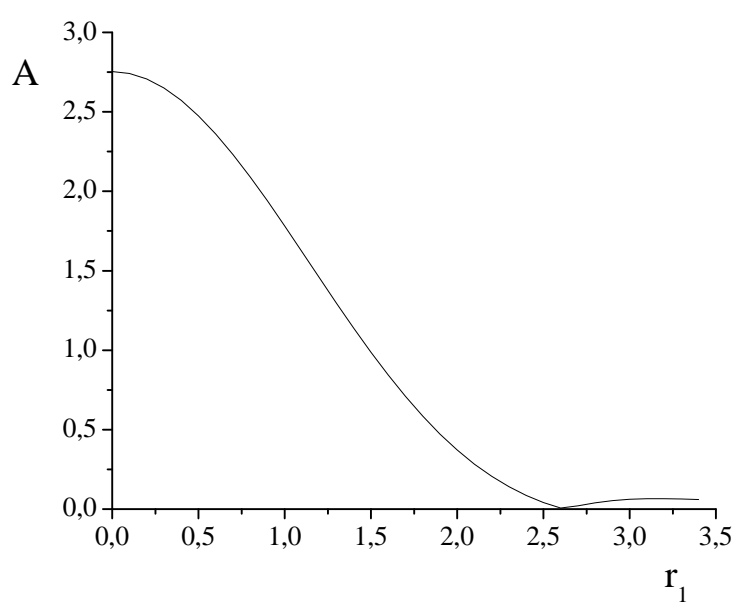

(b)

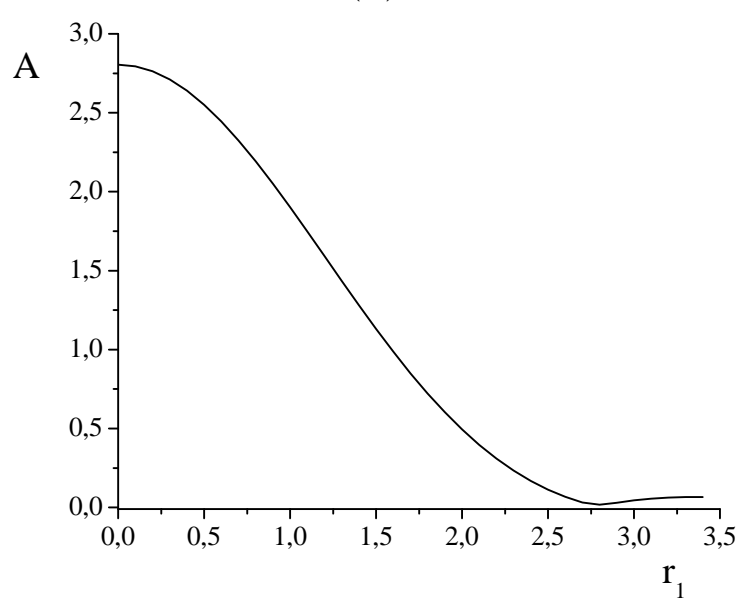

(c)

Figure 5. Wave amplitude at: (a) $z=$ $1.1 z_{\mathrm{R}}$, (b) $z=1.299172 z_{\mathrm{R}}$, (c) $z=$ $1.4 z_{\mathrm{R}}$.

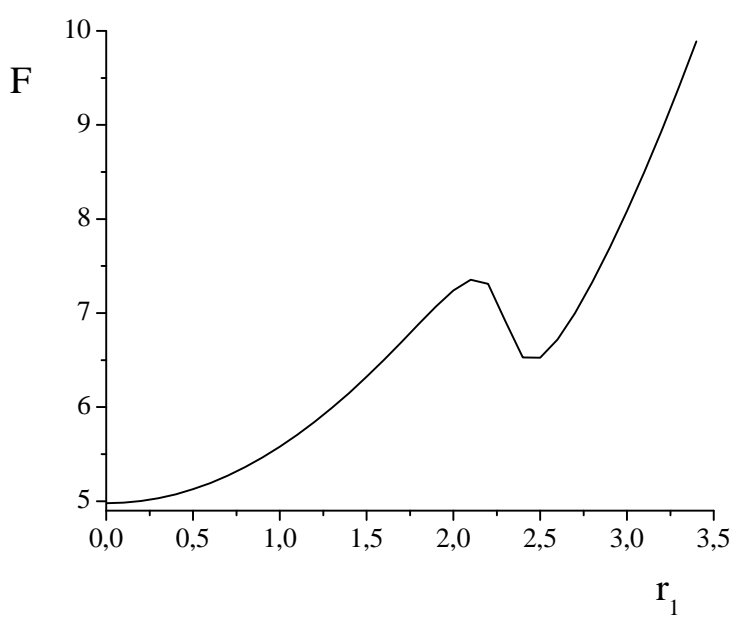

(a)

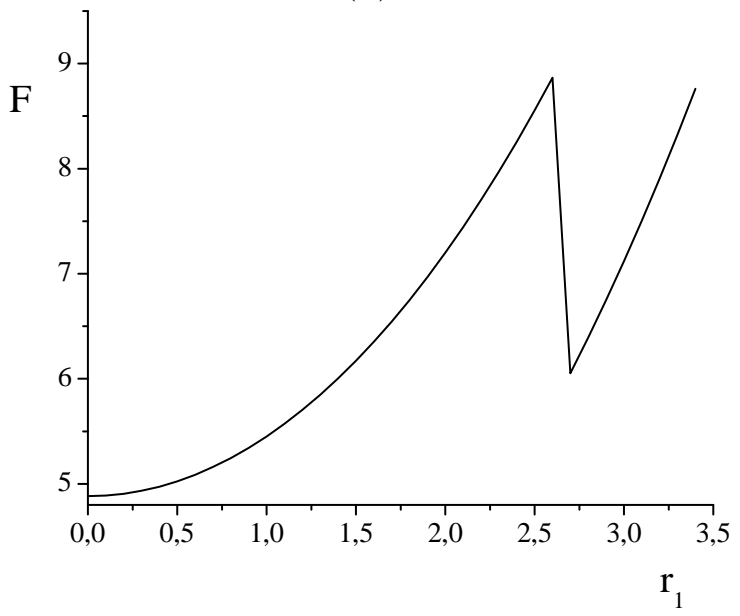

(b)

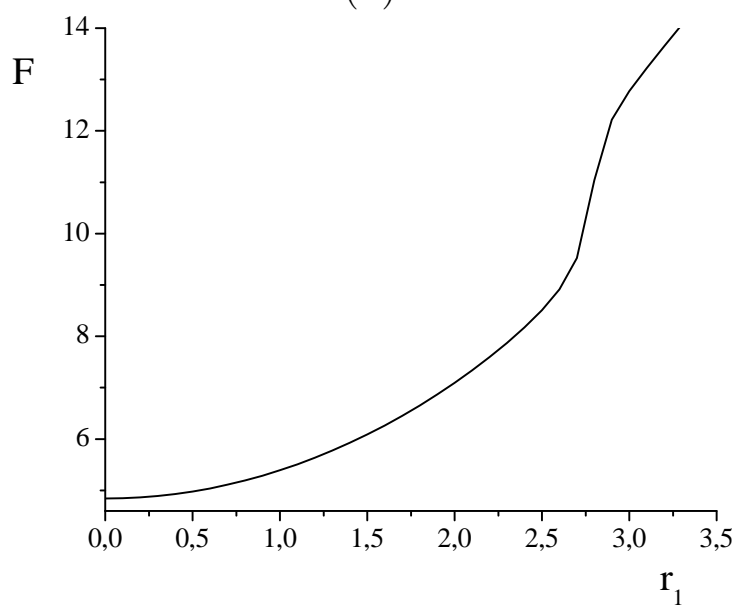

(c)

Figure 6. Wave phase at: (a) $z=1.1 z_{\mathrm{R}}$, (b) $z=1.299172 z_{\mathrm{R}}$, (c) $z=1.4 z_{\mathrm{R}}$. 
once after value $z=1.299172 z_{\mathrm{R}}$, where $z_{\mathrm{R}}$ is Rayleigh length, the amplitude becomes strictly zero. Simultaneously, the phase is curved, there appears a ledge, which at vanishing amplitude tends to $\pi$, and its walls become vertical. When we increment slightly the distance $z$, instead of a ledge there is a trough with vertical walls of height $\pi$ too. The circular edge dislocation is born. The dislocation disappears immediately with the smallest increase of distance $z$. The valley bottom becomes nonzero, the phase jump transforms to a smooth ledge with slanted walls.

\section{Conclusions}

In this paper we found the director profile in the cell with strong homeotropic anchoring under the action of Gaussian light beam. Director reorientation is threshold like, and the value of threshold intensity depends crucially on the ratio between cell thickness and beam half-width. Using the obtained expressions for director profile we investigated the birth of the circular edge phase dislocation in coherent beam with initially smooth wave front. Also, spatial position of the phase singularity at near field as a function of intensity of the input beam was calculated.

\section{Acknowledgement}

We acknowledge useful conversations with M.S.Soskin.

Work was partially supported by INTAS grant $97-635$.

\section{References}

1. Nye J.F., Berry M.V. Dislocations in wave trains. // Proc. Roy. Soc. Lond. A, 1974, vol. 336, p. 165-190.

2. Wright F.J. Wavefront dislocations and their analysis using catastrophe theory. - In: Structural Stability in Physics, Eds. W. Guttinger and H. Eikemeier, Berlin, SpringerVerlag, 1979.

3. Pishnyak O.P., Reznikov Ya.A., Vasnetsov M.V., Yaroshchuk O.V., Gorshkov V.N., Soskin M.S. // Mol. Cryst. Liq. Cryst., 1998, vol. 324, p. 25-30.

4. Zel'dovich B.Ya., Tabiryan N.V., Chilingarjan Yu.S. // ZhETF, 1981, vol. 81, p. 72-83 (in Russian).

5. Khoo I.C., Liu T.H., Yan P.Y. Nonlocal radial dependence of laser-induced molecular reorientation in a nematic liquid crystal: theory and experiment. // J. Opt. Soc. Am. B, 1987, vol 4, p. 115-120.

6. Vasnetsov M., Staliunas K. Optical Vortices. New-York, Nova Science, 1999.

7. Goodman J.W. Introduction to Fourier Optics. McGraw-Hill Book Co., 1996.

8. Zel'dovich B.Ya., Tabiryan N.V. // ZhETF, 1982, vol 82, p. 1126-1142. 


\title{
Самодія гаусового пучка світла в комірці нематичного рідкого кристала
}

\author{
В.Решетняк, С.Субота \\ Фізичний факультет, \\ Київський національний університет ім. Тараса Шевченка, \\ 03680 Київ, просп. Глушкова, 6
}

\section{Отримано 14 серпня 2000 р.}

В статті представлене теоретичне дослідження можливості виникнення оптичної сингулярності у хвильовому фронті лазерного пучка, який проходить через комірку нематичного рідкого кристала (РК). При інтенсивностях нижче певного порогового значення немає викривлення в початково однорідному гомеотропному впорядкуванні РК. Коли інтенсивність світла стає більше цього порогового значення, директор РК відхиляється від своєї початкової орієнтації. Вважається, що зчеплення зі стінками комірки жорстке. Неоднорідний профіль директора приводить до модуляції показника заломлення, який, в свою чергу, можна розглядати як гаусову лінзу, утворену в комірці РК. Ця лінза спричиняє виникнення фазової сингулярності в когерентному пучку з початково гладким хвильовим фронтом. При малих відхиленнях директора в наближенні геометричної оптики можна знайти світлове поле відразу після комірки, i, використовуючи принцип Гюйгенса-Френеля вирахувати знаходження в просторі фазової сингулярності в ближній зоні як функцію від інтенсивності падаючого пучка.

Ключові слова: рідкий кристал, фазові дислокації, фазові сингулярності, світлоіндукований перехід Фредерікса

PACS: $61.30 . G d, 42.65 .-k, 42.70 . D f$ 
